\title{
Prioritas dan Strategi Perencanaan Kerjasama Antar Daerah Dalam Pengembangan Sarana dan Prasarana Wilayah (Studi di Kota Malang, Kabupaten Malang dan Kota Batu)
}

\author{
Ridzki Wibhawani ${ }^{1}$, Soesilo Zauhar ${ }^{2}$, Choirul Saleh ${ }^{2}$ \\ 1Program Magister Ilmu Administrasi Publik, Fakultas Ilmu Administrasi, Universitas Brawijaya \\ ${ }^{2}$ Fakultas IImu Administrasi, Universitas Brawijaya
}

\begin{abstract}
Abstrak
Fenomena urban sprawl, suatu proses perluasan kegiatan perkotaan yang tidak teratur ke wilayah pinggiran saat ini dialami oleh kawasan perkotaan Malang, menyebabkan ketidakefisienan dalam penyediaan sarana dan prasarana wilayah. Studi ini mengkaji pemecahan masalah di atas dari perspektif kerjasama antar daerah, dilatarbelakangi oleh kekuatan politik desentralistik sebagai pendorong penyelesaian masalah pembangunan daerah. Tujuan penelitian adalah mengidentifikasi objek kerjasama dan bentuk kerjasama prioritas dalam pengembangan sarana dan prasarana wilayah serta merumuskan strategi perencanaan berdasarkan faktor pendukung dan penghambat. Jenis penelitian deskriptif dengan metode penelitian campuran (mixed methods). Pengolahan data menggunakan metode AHP (Analytical Hierarchy Process) dan SWOT (Strength Weakness Opportunity Threat). Hasil penelitian menempatkan objek pelayanan air bersih, jaringan jalan dan transportasi umum sebagai objek prioritas. Sedangkan kriteria yang dinilai paling menentukan pemilihan objek kerjasama adalah kebutuhan tinggi/mendesak dan komitmen tinggi. Bentuk kerjasama action network berada pada rangking pertama. Sedangkan aspek yang dinilai paling menentukan bentuk kerjasama adalah aspek peraturan. Sesuai perhitungan SWOT, strategi yang harus diambil adalah : memperkuat komitmen kerjasama untuk kesejahteraan masyarakat, memperkuat segala kemampuan untuk mengatasi tekanan global, perencanaan berdasar kebutuhan melalui penyusunan Master Plan Kerjasama Daerah, meningkatkan komunikasi dan koordinasi antar sektor, memperjelas kewenangan antara pusat, propinsi, kabupaten/kota, mengkomunikasikan perbedaan prioritas kerjasama serta proaktif memperluas jaringan/networking.
\end{abstract}

Kata kunci: Kerjasama Antar Daerah, Mix Methods, Strategi Perencanaan.

\begin{abstract}
Urban sprawl phenomenon, a process of expanding urban irregular activities to suburb area, is currently happening in the city area of Malang. This may cause inefficiencies in the provision of facilities and infrastructures of the area. This study examined the solution of mentioned problems in the perspective of inter-regional cooperation, which is due to decentralized political forces as the driving force toward regional development problem resolution. The purpose of this study was to identify the object of cooperation and forms of cooperation priorities in terms of infrastructure development in the Great Malang area and formulate strategies of planning for inter-regional cooperation based on supporting and inhibiting factors toward inter-regional cooperation. This was descriptive research by nature employed mixed methods research design. Data were analyzed by using a mix of data analysis methods, namely AHP (Analytical Hierarchy Process) and SWOT (Strength Weakness Opportunity Threat) analysis. The results of the study showed that water services, street networks, and public transport as the top priority of the cooperation. The decisive criteria to determine object priorities of cooperation were urgency and high commitment among the regions. Action network as the first rank of cooperation form, while the aspect considered the most decisive towards the cooperation was the regulatory issues. According to the results of SWOT analysis, the strategy that should be taken by the regions are namely maintaining the commitment for the cooperation for the welfare of society; strengthening the competence to cope with global pressures; planning should be based on the needs through the preparation of the Master Plan for Regional Cooperation; improving communication and coordination among relevant sectors; strengthening the authority between the central, provincial, district/city governments; communicating different priorities of the cooperation; proactively expanding the network.
\end{abstract}

Key words: inter-regional cooperation, mix methods, planning strategies

$\begin{array}{ll}\text { Alamat } & \text { Penulis : } \\ \text { Nama } & \text { : Ridzki Wibhawani } \\ \text { Email } & \text { : tridzki@gmail.com } \\ \text { Alamat } & \text { : Pemerintah Kabupaten Malang Jl.Panji Kepanjen }\end{array}$

\section{PENDAHULUAN}

Pertambahan penduduk dalam suatu wilayah perkotaan selalu diikuti oleh peningkatan kebutuhan ruang. Namun, dalam banyak kasus, pertumbuhan perkotaan yang tidak terkendali dan tidak terkoordinasi (urban sprawl) kerap mengundang kerugian terutama ketidakefisienan dalam penyediaan sarana dan prasarana kota. Urban sprawl bertanggung jawab atas perubahan lingkungan fisik, dalam bentuk dan tata ruang kota. Kondisi di atas saat ini dialami oleh Kawasan 
Perkotaan Malang, sebagai kota besar yang menuju kota metropolis. Problematika perkotaan dan dampak ekternalitasnya berkaitan dengan masalah jaringan jalan, transportasi umum, terminal, tempat pembuangan akhir sampah, pelayanan persampahan, air bersih, air limbah, drainase perkotaan, dan pemakaman umum. Dampak eksternalitas tersebut meliputi wilayah Kabupaten Malang dan Kota Batu.

Laju pertumbuhan kota yang pesat di luar kapasitas institusional, administratif dan finansial menuntut penyelesaian yang komprehensif. Namun sampai saat ini belum ada prioritas penanganan dan strategi perencanaan yang tepat dalam mengatasi berbagai dampak urban sprawl yang bersifat lintas batas wilayah administratif. Undang-Undang No. 23/2014 pasal 363 telah menegaskan bahwa urusan pemerintah yang memiliki eksternalitas lintas daerah dan penyediaan layanan publik yang lebih efisien jika dikelola bersama, didasarkan pada pertimbangan efisiensi dan efektifitas pelayanan publik, sinergi dan saling menguntungkan, dapat diselenggarakan melalui kerjasama antar daerah. Melalui kerjasama antar daerah diharapkan banyak potensi yang dimiliki dapat dimanfaatkan untuk kepentingan bersama.

Dalam kaitannya dengan Kerjasama Antar Daerah, Pemerintah Kota Malang, Kabupaten Malang, dan Kota Batu telah menjalin kerjasama dalam penyelenggaraan urusan pemerintah lintas batas sejak tahun 2007. Dari sudut pandang perencanaan, berbagai kerjasama yang sudah dilaksanakan untuk mengatasi masalah yang bersifat lintas wilayah di bidang sarana prasarana wilayah, masih bersifat spasial. Selain itu belum adanya Master Plan Kerjasama Daerah yang menjadi acuan dalam menyelesaikan berbagai masalah lintas batas. Kenyataan ini tidak sejalan dengan komitmen Pemerintah Provinsi Jawa Timur seperti tertuang dalam RPJMD 2014-2019 tentang kebijakan pengembangan sarana dan prasarana wilayah yaitu peningkatan kerjasama antar daerah dalam pengembangan wilayah agar terjadi keselarasan di dalam pembangunan kawasan perbatasan antar provinsi dan antar kabupaten/kota sesuai dengan potensi daerah.

Ketika kebijakan desentralisasi dan otonomi daerah digulirkan, banyak harapan diletakkan di pundak pemerintah daerah. Desentralisasi dimaksudkan sebagai instrumen yang mampu mengakomodasi aspirasi masyarakat yang tergolong majemuk dengan kondisi dan potensi yang beragam pula [1]. Perkembangan konsep dan praktek memperlihatkan bahwa desentralisasi merupakan pembagian kewenangan dan sumberdaya (sharing authority and resources) [2] dan merupakan campuran fungsi dan hubungan administratif, fiskal dan politik [3]. Pembangunan daerah merupakan bagian integral dari pembangunan nasional. Dengan kata lain, pada satu sisi prinsip desentralisasi menciptakan otonomi daerah, pada sisi lain perlu keselarasan rencana pembangunan daerah dengan rencana pembangunan nasional [3].

Local government adalah konsekuensi dari kebijakan desentralisasi. Manfaat yang bisa dipetik dari local government dalam perspektif ini adalah pertama, adanya daya tanggap publik terhadap preferensi individual (public responsiveness to individual preferences). Kedua, local government memiliki kemampuan untuk memenuhi permintaan akan barang-barang publik (the demand for public goods). Ketiga, desentralisasi mampu memberikan kepuasan yang lebih baik dalam menyediakan penawaran barang-barang publik (the supply of public goods) [1].

Dalam konteks kerjasama antar daerah, desentralisasi memberikan ruang kepada daerah untuk merencanakan, melaksanakan dan merasakan hasil dari pembangunan yang dikerjasamakan. Pemerintah terdesentralisasi mengandung potensi masalah koordinasi [4]. Secara teoritis, istilah kerjasama (cooperation) telah lama dikenal dan dikonsepsikan sebagai suatu sumber efisiensi dan kualitas pelayanan [5]. Secara historis, mekanisme kerjasama antar pemerintah lokal telah menjadi isu penting di negara maju [6].

Perencanaan didefinisikan sebagai proses terus menerus yang melibatkan keputusan, atau pilihan, tentang cara-cara alternatif menggunakan sumber daya yang tersedia, dengan tujuan untuk mencapai tujuan tertentu pada suatu waktu di masa depan [7]. Strategi adalah prioritas atau arah keseluruhan yang luas yang diambil oleh organisasi. Strategi adalah pilihan-pilihan tentang bagaimana cara terbaik untuk mencapai misi organisasi [8]. Perencanaan strategik dirumuskan McNamara [9] sebagai "penetapan arah ke mana sesuatu organisasi pada tahun mendatang dan tahun-tahun selanjutnya menuju, disertai dengan penetapan cara bagaimana organisasi tersebut akan sampai ke tujuan dimaksud". Komponen kegiatan utama perencanaan strategik menurut McNamara terdiri atas :

1. Analisis strategik (strategic analysis); merupakan kegiatan semacam "pencermatan" terhadap keadaan lingkungan organisasi. Salah satu alat (instrumen) yang 
sangat populer untuk melakukan analisis strategik adalah analisis SWOT.

2. Penetapan arah tujuan strategik (setting strategic direction); Rumusan tujuan yang baik mengandung sifat "SMARTER" yaitu spesific, measurable, acceptable, realistic, timely, extending dan rewarding.

3. Perencanaan tindakan (action planning); lazim pula disusun suatu rencana tahunan (annual plan), rencana operational (operational plan) atau rencana pelaksanaan kegiatan (management plan).

Strategi harus diformulasikan atau dirumuskan. Analisis SWOT adalah salah satu alat analisis situasional dalam melakukan formulasi strategi [10].

Prasarana dan sarana umum berperan sebagai fasilitas yang dibutuhkan masyarakat luas yang penyediaannya dilakukan secara serentak atau massal. Tingkat pemenuhan fasilitas tersebut menjadi ukuran tingkat kesejahteraan masyarakat [11].

Pendekatan perencanaan wilayah dan kota umumnya dapat dibedakan atas tiga macam yaitu [12]:

a. Pendekatan Perencanaan Rasional Menyeluruh / Rational Comprehensive Approach. Produk perencanaan rasional menyeluruh ini disebut Master Plan, Rencana Umum, General Plan atau Rencana Pembangunan-Development Plan.

b. Pendekatan Perencanaan Terpilah atau Disjointed Incremental Planning Approach.

c. Perencanaan Terpilah Berdasarkan Pertimbangan Menyeluruh atau Mixed Scanning Planning Approach, Proses yang tercakup dalam mixed scanning ini adalah strength, weakness, opportunity dan threat (SWOT) analisis yang hasilnya adalah berupa strategic planning yaitu proses untuk menentukan komponen-komponen yang dianggap prioritas atau utama dan yang tidak.

Berdasar uraian di atas maka penelitian ini bertujuan untuk pertama, mengidentifikasi objek kerjasama bidang sarana dan prasarana wilayah yang menjadi prioritas kerjasama oleh ketiga pemerintah daerah (Kota Malang, Kabupaten Malang dan Kota Batu). Kedua, mengidentifikasi bentuk kerjasama (form of cooperation) dalam pengembangan sarana dan prasarana wilayah di Malang raya dan ketiga, merumuskan strategi perencanaan kerjasama antar daerah berdasarkan analisis faktor pendukung dan penghambat kerjasama. Strategi perencanaan dimaksud dirumuskan dengan cara memahami dengan baik persoalan-persoalan baik internal maupun eksternal, masalah dan potensi yang dimilikinya dan menetapkan langkah mencapai masa depan dengan sumber daya yang tersedia, melalui analisis SWOT, sehingga prioritas atau arah keseluruhan yang luas bisa diambil untuk mencapai tujuan kerjasama pada tahun-tahun mendatang.

\section{METODE PENELITIAN \\ Jenis Penelitian}

Penelitian ini adalah penelitian deskriptif, tidak menggunakan dan tidak melakukan pengujian hipotesis [13] dan dilakukan dengan pendekatan survei. Dalam survei, informasi dikumpulkan dari responden dan menggunakan kuisioner sebagai alat pengumpulan data. Dalam penelitian ini, data hasil kuisioner 1 (kuisioner Analytical Hierarchy Process /AHP) diolah melalui Expert Choice 11 dan kuisioner 2 melalui metode SWOT (Strength Weakness Opportunity Threat) dan hasil akhirnya adalah hasil analisis dari dua metode tersebut.

Analisis data pada penelitian ini menggunakan metoda campuran atau mixed methods, jenis desain penelitian embedded konkuren yaitu metode kualitatif sebagai metode sekunder/pendukung yang kurang dominan ditancapkan (embedded) atau disarangkan (nested) pada metode kuantitatif sebagai metode primer yang dominan Dalam penerapannya, digunakan satu teknik primer (yaitu survei) dan teknik sekunder (wawancara singkat beberapa partisipan yang sudah mengisi instrumen survei) dalam pengumpulan data [14]. Pencampuran (mixing) data muncul pada bagian pembahasan penelitian.

\section{Teknik Pengumpulan Data}

Teknik pengumpulan data dilakukan sebagai berikut : (1) teknik kuisioner atau angket yang dilakukan dalam satu tahap penyebaran kuisioner AHP dan kuisioner SWOT secara bersama, (2) teknik dokumentasi dan (3) wawancara.

Sampel/responden ditentukan dengan teknik purposive sampling. Dalam metode AHP, para responden adalah expert/pakar, terdiri dari unsur pemerintah daerah di pemerintah Kota Malang, pemerintah Kabupaten Malang dan pemerintah Kota Batu yaitu pada Badan Perencanaan Pembangunan Daerah, Bagian/Subbag Kerjasama serta unsur akademisi yaitu dosen jurusan Administrasi Publik Fakultas Ilmu Administrasi dan dosen jurusan Perencanaan Wilayah dan Kota Fakultas Teknik Universitas Brawijaya.

\section{Variabel Penelitian}

Variabel dalam metode AHP terdiri dari kriteria dan alternatif. Kriteria dalam penelitian ini 
ada dua yaitu kriteria untuk menilai alternatif sektor/obyek kerjasama dan kriteria (aspek) untuk menilai alternatif bentuk kerjasama.

Kriteria pemilihan sektor/objek yang dikerjasamakan yaitu: Kebutuhan tinggi dan mendesak (K1), signifikan (K2), Skala ekonomi (K3), Komitmen tinggi (K4), Potensi pengembangan (K5) dan Efektifitas (K6). Lembaga Pengembangan dan Pemberdayaaan Kerjasama Antar Daerah [15] dan [16]. Sedangkan sektor/obyek sarana dan prasarana wilayah yang dikerjasamakan adalah obyek kerja sama pembangunan perkotaan yaitu: terminal (01), instalasi pengelolaan air limbah (IPAL) (O2), tempat pembuangan akhir (TPA) sampah (O3), jaringan jalan(04), transportasi umum (05), pelayanan persampahan (06), jaringan air hujan (07), pelayanan air bersih (08), dan tempat pemakaman umum (09) [17].

Pertimbangan/kriteria dalam memilih bentuk kerjasama antar pemerintah adalah: Aspek sumber daya (A1), Aspek pembiayaan (A2), Aspek Kepemimpinan (A3), Aspek kelembagaan (A4), Aspek peraturan (A5) Aspek peran serta masyarakat (A6) dan Aspek Akuntabilitas Horisontal (A7) [18] dan [19].

Ada 4 (empat) bentuk networking yang dapat dipilih yaitu Information networks (B1), Developmental networks (B2), Outreach networks (B3), dan Action networks (B4) [20].

Analisis AHP (Analytical Hierarchy Process)

AHP yang dikembangkan oleh Thomas L. Saaty, adalah sistem pengambilan keputusan yang efektif atas persoalan kompleks dengan jalan menyederhanakan dan mempercepat proses pengambilan keputusan [21]. Data utama modal AHP adalah persepsi manusia yang dianggap expert atau ahli.

Tahapan-tahapan pengambilan keputusan dalam metode AHP secara garis besar adalah sebagai berikut: Dekomposisi Masalah, Penilaian untuk membandingkan elemen-elemen hasil dekomposisi, dan Sintesis dari Prioritas. Dekomposisi masalah adalah menyusun rancangan hirarki dapat dimulai dari tingkat dasar dengan menderetkan semua alternatif. Tingkat berikutnya harus terdiri atas kriteria untuk mempertimbangkan berbagai alternatif tadi [21]. Puncak sebuah hirarki adalah tujuan (goal) yang akan dicapai.

Dalam AHP, Thomas L. Saaty telah menetapkan batas ketidakkonsistenan (inconsistency) yaitu harus lebih kecil dari $10 \%$ atau 0,100.

Analisis SWOT (Strength Weakness Opportunity Threat)
Sebagai dasar untuk merancang strategi, dilakukan langkah-langkah sebagai berikut :

1. Identifikasi faktor-faktor internal (faktor kekuatan / Strength dan kelemahan / Weakness) dan faktor eksternal (faktor peluang / Opportunity dan tantangan / Threaths).

2. Penyusunan Kuisioner

a) Penilaian terhadap prestasi faktor

b) Penilaian urgensi (tingkat kepentingan) terhadap penanganan-penanganan faktor.

3. Analisis Data

yaitu menyusun matriks strategi internal (IFAS) dan matriks strategi eksternal (EFAS).

4. Penentuan arah strategi dengan menggunakan matriks TOWS yang dikembangkan oleh Weihrich [10].

\section{Analisis Data Mixed Methods}

Proses analisis data dalam penelitian mixed methods terdiri dari tujuh tahapan yaitu reduksi data (data reduction), tayangan data (data display), transformasi data (data transformation), penghubungan data (data correlation), konsolidasi data (data consolidation), komparasi data (data comparation), dan pengintegrasian data (data integration).

\section{HASIL DAN PEMBAHASAN}

Dari hasil penilaian gabungan semua responden, maka perbandingan antar kriteria (level II) dan perbandingan antar alternatif (level III) adalah sebagai berikut :

Tabel 1 Hasil Perhitungan AHP Hirarki 1

\begin{tabular}{|l|c|c|c|}
\hline \multicolumn{1}{|c|}{ Uraian } & \multicolumn{3}{c|}{ LEVEL } \\
\cline { 2 - 4 } & I & II & III \\
\hline Obyek Kerjasama & GOAL & - & - \\
\hline $\begin{array}{l}\text { Kebutuhan tinggi dan } \\
\text { Mendesak }\end{array}$ & - & $0,304^{*}$ & - \\
\hline Signifikan & & & \\
\hline Skala Ekonomi & - & 0,095 & - \\
\hline Komitmen Tinggi & - & 0,101 & - \\
\hline Potensi Pengembangan & - & 0,127 & - \\
\hline Efektifitas & - & 0,156 & - \\
\hline Terminal & - & - & 0,085 \\
\hline IPAL Terpadu & - & - & 0,049 \\
\hline TPA Terpadu & - & - & 0,086 \\
\hline Jaringan Jalan & - & - & 0,198 \\
\hline Transportasi Umum & - & - & 0,115 \\
\hline Pelayanan Persampahan & - & - & 0,097 \\
\hline
\end{tabular}




\begin{tabular}{|l|c|c|c|}
\hline Jaringan Drainase & - & - & 0,099 \\
\hline Pelayanan Air Bersih & - & - & $0,216^{*}$ \\
\hline $\begin{array}{l}\text { Tempat Pemakaman } \\
\text { Umum }\end{array}$ & - & - & 0,054 \\
\hline
\end{tabular}

$\mathrm{CR}=0,01$; Sumber : Pengolahan data, 2015

Tabel 2 Hasil Perhitungan AHP Hirarki 2

\begin{tabular}{|l|c|c|c|}
\hline \multicolumn{1}{|c|}{ Uraian } & \multicolumn{3}{c|}{ LEVEL } \\
\cline { 2 - 4 } & I & II & III \\
\hline Bentuk Kerjasama & GOAL & - & - \\
\hline Aspek Sumber Daya & - & 0,072 & - \\
\hline Aspek Pembiayaan & - & 0,160 & - \\
\hline Aspek Kepemimpinan & - & 0,190 & - \\
\hline Aspek Kelembagaan & - & 0,132 & - \\
\hline Aspek Peraturan & - & $0,206 *$ & - \\
\hline $\begin{array}{l}\text { Aspek Peran Serta } \\
\text { Masyarakat }\end{array}$ & - & 0,089 & - \\
\hline $\begin{array}{l}\text { Aspek Akuntabilitas } \\
\text { Horisontal }\end{array}$ & - & 0,150 & - \\
\hline Information Network & - & - & 0,157 \\
\hline Development Network & - & - & 0,330 \\
\hline Outreach Network & - & - & 0,173 \\
\hline Action Network & - & - & $0,340^{*}$ \\
\hline CR = 01; Sumber $:$ Peng & & & \\
\hline
\end{tabular}

$\mathrm{CR}=0,01 ;$ Sumber : Pengolahan data, 2015

\section{Pembahasan Kriteria Pemilihan Obyek Kerjasama}

Kriteria kebutuhan tinggi dan mendesak menempati rangking pertama sebagai yang paling berpengaruh dalam menentukan prioritas obyek kerjasama (30,4\%). Perencanaan yang baik adalah didasarkan pada kebutuhan. Perencanaan adalah kegiatan terbatas, dalam arti kebutuhan pembangunan lebih besar dari sumber daya yang tersedia, merupakan alasan utama mengapa pengambilan keputusan dalam perencanaan untuk sejumlah program yang diinginkan harus diberikan prioritas.

Sedangkan kriteria komitmen tinggi menempati rangking kedua (21,7\%). Pada dasarnya, regionalisasi desentralistik adalah proses terjadinya region melalui proses/azas musyawarah berdasarkan komitmen bersama antar daerah otonom [22]. Pengarah gerak pada regionalisasi desentralistik lebih diarahkan oleh platform kerjasama yang telah menjadi komitmen yang bersifat non formal. Intergovernmental network adalah salah satu alternatif untuk dapat keluar dari keterbatasan mengelola hubungan yang berbasis hierarkhis dan legal-formal [23].

\section{Pembahasan Obyek Kerjasama}

Hasil penilaian gabungan seluruh responden menempatkan obyek kerjasama pengelolaan air bersih sebagai prioritas pertama (21,6\%). Salah satu alasan diadakannya kerjasama ini adalah ketergantungan / interdependency artinya ada faktor eksternalitas lintas daerah yang dinilai mendesak. Kerjasama pengelolaan pemanfaatan sumber daya alam perlu dipertimbangkan dampaknya pada wilayah lain di luar wilayah administrasinya sendiri.

Sedangkan prioritas kedua adalah obyek kerjasama jaringan jalan $(19,8 \%)$, terutama di wilayah-wilayah perbatasan yang menjadi wewenang dua pemerintah kota/kabupaten yang bertetangga. Kendala yang mungkin dihadapi dalam meningkatkan jaringan jalan di wilayah perbatasan adalah masalah disorientasi prioritas pembangunan dan berkaitan erat dengan tata ruang wilayah perbatasan. Lingkage system adalah kunci jaringan jalan yang melintasi daerah dengan wilayah administratif yang berbeda.

Transportasi umum adalah obyek kerjasama yang sangat penting untuk segera diwujudkan mengingat bahwa di Malang raya, mobilitas penduduk tidak dapat dibatasi oleh wilayah geografis. Dibutuhkan integrasi pelayanan antar moda untuk penanganan transportasi antar kota guna mengantisipasi permasalahan kompleks dan sistemik akibat bertambahnya populasi penduduk, perpindahan serta pergerakan barang dan jasa.

Seiring dengan pertumbuhan perkotaan yang amat pesat, permasalahan drainase perkotaan semakin meningkat pula. Dengan semakin berkurangnya daerah terbuka di kawasan perkotaan yang dapat difungsikan sebagai lahan peresapan air dan didukung pula oleh menurunnya kondisi saluran drainase baik kapasitas, sistem operasi, maupun pengelolaannya telah menyebabkan timbulnya berbagai masalah di sektor drainase. Perubahan tata guna lahan, berkembangnya kawasan terbangun yang tidak terarah, akhirnya mengurangi kawasan terbuka hijau sebagai daerah resapan.

Responden memilih obyek kerjasama pelayanan persampahan pada rangking lima karena dinilai bahwa masing-masing daerah mempunyai cukup kendaraan dan tenaga operasional, sesuai dengan volume sampah yang harus diangkut tiap hari. 
Kerjasama TPA terpadu untuk saat ini belum menjadi prioritas. Masing-masing daerah sudah memiliki rencana pengelolaan sampah yang tidak membutuhkan kerjasama daerah lain. Namun Pemerintah Kota Malang merencanakan obyek TPA terpadu ini untuk segera dikerjasamakan. Kota Malang menjadi pihak inisiator pembentukan TPA regional.

Pengelolaan terminal dinilai bukan obyek sarana prasarana yang penting untuk dikerjasamakan karena secara lokasi menjadi kewenangan masing-masing daerah.

Pemakaman Umum menempati rangking bawah dari pemilihan obyek kerjasama. Masingmasing daerah berpendapat bahwa pengadaan lahan dan pengelolaan untuk TPU cukup diatasi sendiri tanpa melibatkan daerah lain.

IPAL terpadu belum dijadikan pilihan oleh responden untuk dikerjasamakan karena dinilai bahwa obyek ini untuk saat ini cukup dikelola tanpa melibatkan daerah lain yang bertetangga.

Pembahasan Aspek Pemilihan Bentuk Kerjasama

Aspek yang paling penting dalam pemilihan bentuk kerjasama adalah aspek peraturan $(20,6 \%)$. Upaya harmonisasi dan penyerasian pelayanan publik melalui berbagai bentuk kerjasama daerah tidak lepas dari penyamaan persepsi tentang berbagai peraturan, kebijakan, konsep dan pengelolaan terkait tema kerjasama. Payung regulasi yang ada harus mampu menguatkan, menumbuhkembangkan inisiatif pembangunan wilayah yang mengedepankan komitmen bersama para pelaku pembangunan ini.

Peraturan perundang-undangan terkait kerjasama mengacu kepada Undang-undang No 32 /2004, sementara sekarang UU yang dipakai adalah UU No 23/2014. Sehingga seyogyanya PP atau Permendagri menyangkut kerjasama antar daerah mengacu kepada UU yang baru. Karena belum adanya PP pengganti dari PP no 50/2007 dan Permendagri No.22/2009 yang mengacu kepada UU No 23/2014, maka tata cara pelaksanaan kerjasama antar daerah tetap menggunakan PP no 50/2007 dan Permendagri No.22/2009. Beberapa perubahan dalam peraturan perundang-undangan terkait kerjasama adalah :

1. Dalam PP No 50/2007 disebutkan pembentukan badan kerja sama, sementara UU No.23/2014 pasal 364 menyebutkan pembentukan sekretariat kerja sama.

2. Dalam UU No. 23/2014 disebutkan secara eksplisit tentang kerjasama wajib (pasal 364) dan kerjasama sukarela (pasal 365), yang sebelumnya dalam UU No.32/2004 tidak disebutkan.

3. Dalam pasal 195 UU No 32/2004, pengaturan kerjasama antar pemerintah daerah diatur dalam bentuk keputusan kerjasama, tetapi UU No 23/2014 tidak menyebutkan secara eksplisit tentang bentuk hukum kerjasama. Sedangkan pasal 5 PP No.50/2007 mengaturnya dalam bentuk perjanjian. Permendagri No.22/2009 mengenal istilah "kesepakatan bersama" sebagai bentuk kesepakatan sebelum ditandatanganinya perjanjian. Keputusan maupun peraturan merupakan tindakan sepihak yang ditujukan kepada pihak lain, sedangkan perjanjian yang dibentuk oleh para pihak dan dilaksanakan oleh para pihak serta dipertahankan atau ditegakkan sendiri oleh para pihak yang melaksanakan perjanjian [24].

Aspek kepemimpinan menempati rangking kedua (19\%). Kepemimpinan didefinisikan sebagai kapasitas pribadi untuk menampung dan alamat lintas batas pemerintahan secara efektif. Kepemimpinan adalah kondisi yang diperlukan untuk memajukan kerjasama antar pemerintah. Menurut penelitian tentang kebijakan perkotaan dan administrasi publik, kepemimpinan menjadi sangat penting dalam menghadapi masalah integrasi horizontal atau vertikal dalam organisasi.

Aspek pembiayaan; dukungan pembiayaan bersama, menempati rangking ketiga. Pembiayaan pembangunan merupakan masalah klasik. Namun sebenarnya, salah satu urgensi pemanfaatan Regional Management dalam kerjasama antar daerah adalah adanya peluang memperolah sumber dana dari program pembangunan baik nasional maupun internasional [22].

\section{Pembahasan Bentuk Kerjasama}

Hasil penilaian gabungan memilih bentuk kerjasama Action Network (33\%) sebagai prioritas, dimana daerah-daerah yang menjadi anggota secara bersama-sama menyusun program aksi bersama, dilaksanakan bersama atau oleh lembaga pelaksana kerjasama (BKAD atau Sekber). Aksi bersama tersebut diharapkan dapat memecahkan permasalahan infrastruktur wilayah walaupun wacana kerjasama "Malang raya" sebagai konsep pembangunan regional belum sepenuhnya dan masih baru, belum terlaksana dengan baik terutama untuk pengelolaan sumber daya atau strategi.

\section{Hasil Analisis SWOT}

Berdasarkan hasil kuisioner SWOT disusunlah matriks strategi internal dan matriks strategi 
eksternal hasil pembobotan IFAS-EFAS kerjasama antar daerah adalah sebagai berikut :

Tabel 3 Internal Strategic Factors Analysis Summary (IFAS)

\begin{tabular}{|c|c|c|c|c|}
\hline \multicolumn{5}{|c|}{ Faktor Internal } \\
\hline No & $\begin{array}{c}\text { Kekuatan / Strength } \\
\text { S }\end{array}$ & Bobot & Rating & $\begin{array}{c}\text { Bobot } \mathrm{x} \\
\text { Rating }\end{array}$ \\
\hline 1 & $\begin{array}{l}\text { Komitmen tinggi } \\
\text { untuk bekerja sama }\end{array}$ & 0,071 & 4 & 0,248 \\
\hline 2 & $\begin{array}{l}\text { Tenaga / sdm yang } \\
\text { mendukung } \\
\text { pelaksanaan KAD }\end{array}$ & 0,065 & 3 & 0,212 \\
\hline 3 & $\begin{array}{l}\text { Komunikasi } \\
\text { efektif/intensif antar } \\
\text { pemda }\end{array}$ & 0,061 & 3 & 0,183 \\
\hline 4 & Koordinasi terarah & 0,057 & 3 & 0,166 \\
\hline 5 & $\begin{array}{l}\text { Kapasitas/sarana } \\
\text { pendukung yang } \\
\text { memadai }\end{array}$ & 0,061 & 3 & 0,185 \\
\hline 6 & $\begin{array}{l}\text { Perencanaan } \\
\text { berdasar kebutuhan }\end{array}$ & 0,070 & 3 & 0,236 \\
\hline 7 & Kebijakan yang jelas & 0,070 & 3 & 0,238 \\
\hline 8 & $\begin{array}{l}\text { Manajemen dan } \\
\text { kepemimpinan yang } \\
\text { kuat. }\end{array}$ & 0,070 & 3 & 0,243 \\
\hline 9 & $\begin{array}{l}\text { Kepemimpinan } \\
\text { politik / political will }\end{array}$ & 0,071 & 4 & 0,248 \\
\hline 10 & $\begin{array}{l}\text { Ketersediaan untuk } \\
\text { memulai konsep } \\
\text { manajemen regional, } \\
\text { dan jaringan }\end{array}$ & 0,067 & 3 & 0,226 \\
\hline \multicolumn{2}{|r|}{ Jumlah } & & & 2,184 \\
\hline No & $\begin{array}{l}\text { Kelemahan / } \\
\text { Weakness W }\end{array}$ & Bobot & Rating & $\begin{array}{c}\text { Bobot } \mathrm{x} \\
\text { Rating }\end{array}$ \\
\hline 1 & $\begin{array}{l}\text { Kemampuan/potensi } \\
\text { menyelenggarakan } \\
\text { kerjasama }\end{array}$ & 0,063 & 3 & 0,191 \\
\hline 2 & $\begin{array}{l}\text { Ego daerah / } \\
\text { fanatisme daerah }\end{array}$ & 0,059 & 3 & 0,176 \\
\hline 3 & $\begin{array}{l}\text { Keterbatasan know } \\
\text { how (pengetahuan) } \\
\text { para pelaksana KAD }\end{array}$ & 0,051 & 3 & 0,132 \\
\hline 4 & Keterbatasan dana & 0,050 & 2 & 0,122 \\
\hline 5 & $\begin{array}{l}\text { Belum adanya } \\
\text { payung hukum dan } \\
\text { panduan operasional } \\
\text { kerjasama antar } \\
\text { daerah }\end{array}$ & 0,057 & 3 & 0,150 \\
\hline 6 & $\begin{array}{l}\text { Kebiasaan } \\
\text { penggunaan pola } \\
\text { sentralistik }\end{array}$ & $\begin{array}{c}0,06 \backslash 5 \\
7\end{array}$ & 3 & 0,146 \\
\hline & Jumlah & & & 0,917 \\
\hline
\end{tabular}

Sumber : Pengolahan Data, 2015

Tabel 4 Eksternal Strategic Factors Analysis Summary (EFAS)

\begin{tabular}{|c|l|c|c|c|}
\hline \multicolumn{5}{|c|}{ Faktor Eksternal } \\
\hline No & $\begin{array}{c}\text { Peluang / } \\
\text { Opportunity O }\end{array}$ & Bobot & Rating & $\begin{array}{c}\text { Bobot x } \\
\text { Rating }\end{array}$ \\
\hline 1 & $\begin{array}{l}\text { Kerjasama } \\
\text { dengan lembaga } \\
\text { donor }\end{array}$ & 0,090 & 3 & 0,269 \\
\hline
\end{tabular}

\begin{tabular}{|c|c|c|c|c|}
\hline 2 & $\begin{array}{l}\text { Penyatuan } \\
\text { sumber daya }\end{array}$ & 0,095 & 3 & 0,298 \\
\hline 3 & $\begin{array}{l}\text { Keterlibatan } \\
\text { masyarakat dlm } \\
\text { pelaksanaan KAD }\end{array}$ & 0,095 & 3 & 0,305 \\
\hline 4 & $\begin{array}{l}\text { Akuntabilitas } \\
\text { horisontal jelas }\end{array}$ & 0,097 & 3 & 0,318 \\
\hline \multicolumn{2}{|r|}{ Jumlah } & & & 1,190 \\
\hline No & $\begin{array}{c}\text { Ancaman / } \\
\text { Threats T }\end{array}$ & Bobot & Rating & $\begin{array}{l}\text { Bobot } x \\
\text { Rating }\end{array}$ \\
\hline 1 & Tekanan global & 0,094 & 3 & 0,292 \\
\hline 2 & $\begin{array}{l}\text { Keterbatasan } \\
\text { jejaring/ } \\
\text { networking }\end{array}$ & 0,082 & 3 & 0,215 \\
\hline 3 & $\begin{array}{l}\text { Gap potensi } \\
\text { sumberdaya }\end{array}$ & 0,092 & 3 & 0,276 \\
\hline 4 & $\begin{array}{l}\text { Perbedaan } \\
\text { prioritas dalam } \\
\text { pemilihan sumber } \\
\text { daya }\end{array}$ & 0,092 & 3 & 0,276 \\
\hline 5 & $\begin{array}{l}\text { Tendensi } \\
\text { mengumpulkan } \\
\text { PAD (pendapatan } \\
\text { asli daerah) }\end{array}$ & 0,090 & 3 & 0,263 \\
\hline 6 & $\begin{array}{l}\text { Adanya grey area } \\
\text { kewenangan } \\
\text { antara pusat, } \\
\text { propinsi, } \\
\text { kabupaten/kota }\end{array}$ & 0,083 & 3 & 0,224 \\
\hline 7 & $\begin{array}{l}\text { Lemahnya } \\
\text { koordinasi antar } \\
\text { sektor / daerah. }\end{array}$ & 0,090 & 3 & 0,254 \\
\hline & Jumlah & & & 1,798 \\
\hline
\end{tabular}

Sumber : Pengolahan Data, 2015

Berdasarkan hasil pembobotan matriks IFAS dan EFAS, dapat dihitung selisih skor faktor $S$ dan $W$ adalah 1,267. Selisih skor faktor $O$ dan $T$ adalah negatif 0,608 (kuadran 2, ST strategies).

\section{Pembahasan Alternatif Strategi dalam rangka Perencanaan Kerjasama Antar Daerah}

ST Strategies merupakan berbagai strategi yang dihasilkan melalui menggunakan kekuatan (strengths) yang dimiliki untuk menghindari/memperkecil berbagai ancaman (threats). Harus dilakukan upaya mobilisasi sumber daya yang merupakan kekuatan organisasi untuk memperlunak ancaman dari luar tersebut, bahkan kemudian merubah ancaman itu menjadi sebuah peluang. Dalam rangka perencanaan kerjasama antar daerah, alternatif strategi adalah :

1. Memperkuat komitmen kerjasama untuk kesejahteraan masyarakat

Hal ini sesuai dengan pernyataan Ben-Meir bahwa maksud/niat utama desentralisasi adalah untuk memajukan pembangunan yang mampu menghasilkan manfaat bagi masyarakat [25]. 
2. Memperkuat segala kemampuan untuk mengatasi tekanan global. Dalam kerjasama regional, konsekuensinya adalah harus dilakukan pembenahan kemampuan institusi pemerintahan di daerah [26], diantaranya melalui:

a. Pendidikan dan pelatihan sumber daya aparatur yang berkaitan dengan perencanaan dan pelaksanaan kerjasama antar daerah serta penyusunan strategi investasi;

b. Meningkatkan kapasitas kelembagaan pemerintah daerah melalui penataan kelembagaan daerah.;

c. Mengoptimalkan peran TKKSD (Tim Koordinasi Kerja Sama Daerah) di setiap pemerintah daerah, sesuai dengan Permendagri No 22/2009 tentang tugas TKKSD;

d. Mengaktifkan potensi endogen pembangunan wilayah yaitu tenaga kerja, modal, infrastruktur, potensi pasar, sumber daya alam, ruang dan lokasi, keindahan alam, budaya politik, kepastian hukum, otonomi daerah [22].

3. Perencanaan berdasarkan kebutuhan melalui penyusunan Master Plan Kerjasama Daerah yang memuat Rencana Aksi Lima Tahunan dengan melibatkan Tim Koordinasi Kerjasama Daerah (TKKSD) Pemerintah Kabupaten/Kota dan Lembaga/Instansi terkait lainnya dengan difasilitasi oleh Biro Otonomi Daerah Sektretariat Daerah Provinsi, dengan melibatkan Tim Pakar, Praktisi (Profesional), dan unsur pemerintahan terkait, mengaju kepada teori Triple Helix. Belum adanya Master Plan Kerjasama Daerah selama ini menyebabkan kerjasama yang dilakukan tidak disertai dengan perencanaan program yang matang, action plan tahunan serta penyediaan anggaran yang memadai. Program/kegiatan kerjasama selayaknya dilakukan dalam kerangka kebutuhan nyata daerah dan merupakan program prioritas daerah;

4. Meningkatkan komunikasi dan koordinasi antar sektor

Komunikasi dan koordinasi antar sektor dalam Intergovernmental network, perlu menekankan pada dimensi "collective action" (tidak ada aktor tunggal) dimana dengan collective action tersebut, tujuan dapat dinegosiasikan, pemahaman bersama didorong dan kompromi dibuat di antara daerah-daerah yang tergabung dalam sebuah forum kerjasama daerah.
5. Memperjelas kewenangan antara pusat, propinsi, kabupaten/kota

Yaitu melalui penguatan regulasi, penyiapan model, dan fasilitasi kerjasama antar daerah. Peran provinsi bersifat koordinatif dan memberikan fasilitas kebijakan sesuai kewenangan.

6. Mengkomunikasikan perbedaan prioritas kerjasama

Prioritas yang berbeda pada perencanaan dan strategi dapat mengakibatkan tumpang tindih baik atau tidaknya dalam penyediaan infrastruktur dasar pembangunan perkotaan.

7. Proaktif memperluas jaringan/ networking Mengintesifkan kerjasama yang sudah terjalin dan proaktif memanfaatkan struktur jejaring. Jejaring adalah sebuah konfigurasi dari para aktor yang berada pada hubungan saling membutuhkan (interdependency) [22].

\section{KESIMPULAN}

Berdasarkan hasil penelitian dan pembahasan, maka dapat ditarik kesimpulan sebagai berikut:

1. Hasil penilaian AHP menempatkan obyek kerjasama pelayanan air bersih, jaringan jalan, dan transportasi umum sebagai prioritas utama. Sedangkan kriteria yang dinilai paling menentukan prioritas obyek kerjasama adalah kebutuhan tinggi/mendesak dan komitmen tinggi.

2. Hasil penilaian AHP menempatkan bentuk kerjasama action network pada rangking pertama, sedangkan aspek yang dinilai paling menentukan bentuk kerjasama adalah aspek peraturan dan kepemimpinan;

3. Sesuai dengan matriks strategi TOWS dan perhitungan SWOT, strategi yang harus diambil adalah ST strategies.

\section{SARAN}

Berdasarkan kesimpulan di atas, maka disampaikan saran sebagai berikut:

1. Mengkomunikasikan perbedaan prioritas obyek kerjasama antar pemerintah daerah melalui forum-forum kerjasama dan koordinasi intensif;

2. Menyamakan persepsi tentang berbagai peraturan, kebijakan, konsep dan pengelolaan terkait kerjasama serta menetapkan langkahlangkah menyusun aksi bersama (action network).

3. Melakukan pembenahan kemampuan internal institusi, lebih khusus dalam bidang pemerintahan dalam bentuk Pengembangan Kapasitas atau Capacity Bulding. Serta proaktif memperluas jaringan salah satunya dengan 
memanfaatkan teknologi informasi. Aparatur pemerintah sebagai pelaksana kebijakan perlu meningkatkan pemahaman tentang Regional Management sebagai salah satu bentuk instrumen pembangunan nonformal keruangan.

4. Menyusun Master Plan Kerjasama Daerah melibatkan Tim Koordinasi Kerjasama Daerah (TKKSD) Pemerintah Kabupaten/Kota dan Lembaga/Instansi terkait lainnya dengan difasilitasi oleh Biro Otonomi Daerah Sektretariat Daerah Provinsi Jawa Timur.

\section{DAFTAR PUSTAKA}

[1]. Muluk, Khoirul, 2006. Desentralisasi dan Pemerintahan Daerah. Bayumedia Publishing. Malang.

[2]. Cheema, Shabbir and Rondineli, Dennis. 1983. "From Government Decentralization to Decentralized Governance".

[3]. Saksono, Afsdy. 2013. "Keselarasan Dalam Perencanaan Pembangunan Multilevel Suatu Tinjauan Pustaka". Dalam Jurnal Administrasi Negara I Vol 9 I No. 2 I 2013.

[4]. Spahn, Paul Bernd. 2001. Institutional Arrangements for Coordination Among Governments in Germany.Goethe University at Frankfurt. http://mpra.ub.unimuenchen.de/13243/MPRA Paper No. 13243, posted 8. February 2009 05:42 UTC.

[5]. Rosen, Ellen Dorce. 1993. Improving Public Sector Productivity. Concepts and Practice. USA. Sage Publications.

[6]. Henry, Nicholas. 1995. Public Administration and Public Affair. New Jersey : Prentice Hall.

[7]. Conyers, Diana, dan Peter Hills, 1990, An Introduction to Development Planning in The Third World. John Wiley \& Sons. New York.

[8]. Allison, Michael dan Jude Kaye, 2005, Strategic Planning for Nonprofit Organizations, A Practical Guide and Workbook, New Jersey: Jhon Wiley \& Sons, Inc.

[9]. McNamara, Carter, MBA, PhD, Authenticity Consulting, LLC. Basic Overview of Various Strategic Planning Models (Including Basic, Issue-Based, Alignment, Scenario and Organic)Copyright 1997-2006. Adapted from the Field Guide to Nonprofit Strategic Planning and Facilitation.

[10]. Solihin, Ismail, 2012. Manajemen Strategik. Erlangga. Jakarta.

[11]. Sadyohutomo, Mulyono. 2009. Manajemen Kota dan Wilayah, Realita dan Tantangan. Penerbit Bumi Aksara. Jakarta.
[12]. Sujarto, Djoko. 2001. Pilihan Strategis : Suatu Teknik Pengambilan Keputusan Dalam Perencanaan Wilayah dan Kota. Penerbit ITB. Bandung.

[13]. Faisal, Sanapiah, 2010. Format-format Penelitian Sosial. Rajagrafindo Persada. Jakarta.

[14]. Creswell, John W. 2014. Research Design Pendekatan Kualitatif, Kuantitatif, dan Mixed. Diterjemahkan oleh Achmad Fawaid. Pustaka Pelajar. Yogyakarta.

[15].http://lekadnews.blogspot.com/2011/03/sk enario-kerja-sama-antardaerah-skad.html

[16]. Kurtz, Thomas S., 2002. Intergovernmental Cooperation Handbook. Fifth Edition .. Pennsylvania Association of Councils of Government.

[17]. Peraturan Menteri Dalam Negeri Nomor 69 Tahun 2007 Tentang Kerja Sama Pembangunan Perkotaan.

[18]. Mason, M. (2006). Collaborative Partnership for Urban Development : A study of the Vancouver agreement. (Research paper in Environmental and Spatial Analysis No.108). Retrieved from http://eprints.Ise.ac.uk/3715/1/Collaborativ e partnerships for urban development.pd $\underline{f}$

[19]. Hartanto, Eko Yudhi, 2009. Konsep kelembagaan Kerjasama Anrdaerah Dalam Pengelolaan TPA Regional ( Kabupaten Hulu Sungai Utara dan Kabupaten Tabalong). Tesis, UNDIP. Magister Teknik Pembanguan Wilayah dan Kota.

[20]. Agranoff, Robert, 2003, "A New Look at the Value-Adding Functions of Intergovernmental Networks", Paper presented for Sevent National Public Management Research Conference, Georgetown University, October 9-11, 2003.

[21]. Saaty, T.L. 1993. Pengambilan Keputusan Bagi Para Pemimpin : Proses Hirarki Analitik untuk Pengambilan Keputusan dalam Situasi yang Kompleks. Translation. Diterjemahkan oleh Ir. Liana Setiono. PT. Pustaka Binaman Pressindo. Jakarta.

[22]. Abdurahman, Benyamin, 2009. Pemahaman Dasar Regional Management dan Regional Marketing, Edisi 2. Penerbit Lekad. Semarang.

[23]. Domai, Tjahjanulin, 2010. Implementasi Kebijakan Kerjasama Antar Daerah Dalam Pemanfaatan Sumberdaya Daerah. Disertasi Doktor Ilmu Administrasi Publik. Universitas Brawijaya. 
[24]. Sujatmoko, Emanuel. 2012. Bentuk Hukum dan Penyelesaian Sengketa Kerjasama Antar Pemerintah Daerah. Disertasi Doktor IImu Hukum. Universitas Brawijaya.

[25.] Ben-Meir, 2008. "National Sovereignty through Decentralization. A CommunityLevel Approach to Development, Reconciliation and Stability in Conflict Areas in the Middle East and North Africa".

[26]. Utomo, Tri Widodo, 2012. Prospek Pengembangan Kerjasama Antar Daerah Kabupaten/Kota di Kalimantan Timur Dalam Penyelenggaraan Urusan Pembangunan dan Pelayanan Masyarakat. Dalam Jurnal Borneo Administrator / Volume 8 | No. 1 | 2012. Samarinda. 